\title{
Une nouvelle direction de recherche pour la coopération au développement
}

Eine neue Suchrichtung für die Entwicklungszusammenarbeit

\section{Rudolf Högger}

\section{(2) OpenEdition}

1 Journals

Édition électronique

URL : http://journals.openedition.org/aspd/1401

DOI : 10.4000/aspd. 1401

ISSN : 1663-9669

Éditeur

Institut de hautes études internationales et du développement

\section{Édition imprimée}

Date de publication : 1 janvier 1991

Pagination : 255-270

ISSN : 1660-5934

\section{Référence électronique}

Rudolf Högger, «Une nouvelle direction de recherche pour la coopération au développement »,

Annuaire suisse de politique de développement [En ligne], 10 | 1991, mis en ligne le 14 avril 2013,

consulté le 10 décembre 2020. URL : http://journals.openedition.org/aspd/1401 ; DOI : https://doi.org/ 10.4000/aspd. 1401

Ce document a été généré automatiquement le 10 décembre 2020.

(C) The Graduate Institute I Geneva 


\section{Une nouvelle direction de recherche pour la coopération au développement}

Eine neue Suchrichtung für die Entwicklungszusammenarbeit

\section{Rudolf Högger}

\section{NOTE DE L'ÉDITEUR}

Lire l'article original en allemand dans Schweizerisches Jahrbuch für Entwicklungspolitik :

«Eine neue Suchrichtung für die Entwicklungszusammenarbeit », http://

sjep.revues.org/1222. 